\title{
Reflections on the Development of the Art Discipline Education in Chinese Universities
}

\author{
Chunxiao $\mathrm{CaO}^{1,}$,, Yujia Liü, b \\ ${ }^{1}$ School of Art, Shandong University(Weihai), Weihai 264209, China; \\ ${ }^{2}$ School of Mechanical Engineering, Shandong University, Jinan 250061, China. \\ a3210366@qq.com, b 18867872@qq.com
}

Keywords: Teaching standards; disciplinarily; education; artistic disciplines.

\begin{abstract}
Since the art specialty has become an independent subject, the youngest professional category of Chinese higher education has been developing rapidly. But because of various historical reasons, the discipline and independence of art are influenced by the traditional thinking of science and education. We hope that through this for developed countries in Europe and the United States of the art of history of the development of the discipline of the introduction, the main problems facing a rethink of China's University at the present stage, puts forward solving ways and ideas, in order to promote the benign positive developments in art disciplines of the University.
\end{abstract}

\section{Introduction}

In 2012, art independent from the traditional categories of literature, become China's higher education subject category latest an independent category. According to the 2013 art education industry analysis report "released data show, cut-off to 2012 national art culture education of colleges and universities to 1679, attend the university entrance exam artistic kind of examinee number of nearly a million, accounting for about $10 \%$ of the total number of students in the college entrance examination. These institutions in addition to the art of professional colleges and universities, and a large number of normal colleges, private colleges and higher occupation colleges, short time to create a large number of institutions and professional art education in China's development and prosperity of building good foundation platform, but we should remain sober, the growth of Chinese higher education in the field of art education has come to a need from quantitative change to qualitative change, from the popularity of art education to improve the culture quality of the critical period. Many colleges and universities in the existing art education thought and the concept of training also needs to be updated and improved. According to the subject of art of the development course in Europe and America for major countries of higher art education, University of the arts development is to and professional art colleges in talent cultivation direction and curriculum should have bigger difference, and the difference is precisely what China University in the development of artistic disciplines is one of the important direction to consider.

\section{The Development Course of Art Education in American and European Universities}

University modern sense was born in medieval Europe. But because traditional society like China for the "arts and crafts artisans' social status discrimination, from the University of school early, various art-related visual arts have been excluded from teaching courses outside the university system, such as sculpture, painting, metal decoration, depicting the like. Until the Renaissance, the Enlightenment bourgeois who waved "liberty, equality, fraternity" spirit banner, setting off a peak of humanism. In this case, art education was only introduced into the university setting inside.

In 1868, Oxford, Cambridge and London, three British universities have established Slade Professorship of Fine Art, the move is the English-speaking countries will be extended to artistic concepts first attempt universities. Served as the first session of the Oxford Chair Slade art lectures crown is the famous British art critic, art Thinking Enlightenment • John Ruskin ( $1819 \sim 1900)$. He is also the most important nineteenth-century Britain, "Arts and Crafts" movement of spiritual leader • 
John Ruskin can say is the world of modern art and design guide. Today, the University of Oxford in the Ruskin School of Drawing is to commemorate him with his named. At Oxford University, John Ruskin - Push row comprehensive art education system includes measures following aspects: First, the hosts art theoretical lectures; Second, a work of art galleries and museum; three open hands painting practice course. - John Ruskin as a great educator, for the concept of art talents, enlightenment and covers not only professional art education, and includes daily arts teenagers and college students, including adoption. He Oxford University education practice for the subsequent conduct of the University of arts education, especially for basic arts education system in the United States to build comprehensive schools provide an important guide.

Since the nineteenth century, America's most famous three universities: Harvard, Yale and Princeton University, and their three modes of art education laid the foundation for the United States University of the Arts Education Discipline System. These three arts curriculum leading universities in Germany and the UK are affected very deep in thought on art education, curriculum, teaching system, teaching contents and methods can be seen in Germany and the UK marks. American universities teaching artistic disciplines pursued diversified teaching approach combining pragmatism and rationalism, the basic starting point is to serve the interests of the market, the goal of all art teaching compliance orders and demand in the market-oriented development strategy. In the United States into the twentieth century, many American universities training mode of artistic disciplines to produce a very influential change measures is to gradually establish art education programs to choose which courses through the University's plan. As an important form of adjustment of teaching art courses there is a significant change from a small single body type and gradually developed into a diverse, reasonable layout, with considerable depth and breadth of curriculum system. We all know that basic education system curriculum of American universities is the world's most complex and most comprehensive large curriculum, every college student can choose their elective courses from the direction of the basic course system hundreds of doors, and there Art courses occupy a very important part. According to research conducted by the American Society of College Art fifty institutions of higher education in the United States of the 1940s it has been set up more than eight hundred kinds of art history courses. Such as Harvard University art history courses offered include various types of general and specialized history, up to 45 numbers, type and scope is very broad. American university system in basic course in art history gradually emerged in China as the core curriculum of Liberal Arts education system. Let popularize basic knowledge of art and build quality has become the development direction of University of the Arts disciplines. This is how the development of the university artistic disciplines, out of professional colleges and art provides a different direction a good example guideline.

\section{Road to the Development of Education in Chinese Universities}

The first country in the early last century began to explore artistic disciplines specialized education. Zhang founded in 1905 Sanjiang Normal School was renamed Liangjiang gifted class Normal School, the first in China to set up arts faculties in higher education institutions, training for China's first generation of modern art teachers and art education personnel. April 1918 famous educator Cai Yuanpei advocate the creation of China's first professional art education institutions - National School of Fine Arts that is now the predecessor of Beijing Central Academy of Fine Arts, created a precedent for modern Chinese art education, Mr. Zheng Jin served as the first president. In 1928, Cai, Lin established China's first comprehensive national higher art education institutions, is also China's first modern undergraduate and graduate degrees cultured highest art educational institutions - "National Art Academy," which is now the China Academy of Art Academy, which is recognized by UNESCO earliest Chinese University of Fine Arts. In these early professional art schools, although the introduction of Art and direct teaching mode from the West, but the shortcoming is not a lot of educational philosophy and butt fusion and unique aesthetic imagery and evaluation criteria of the Chinese nation. 
After the founding of New China, the Chinese University of artistic disciplines development into two stages. In order to study the Soviet Union in 1952, a series of higher education faculties adjustment. Many Chinese universities are broken down into a number of professional institutions; the same fate art discipline is also facing a lot of the newly established School of Music and Fine Arts. For example, the predecessor of the Central Conservatory of Music is part of Yenching University Department of Music, Nanjing Art Institute is part of the Department of Shandong University of Art predecessor. Former University of Arts faculties no longer exists, this situation has continued for three decades. In 1983, Xiamen University offers artistic disciplines, marking the return to Chinese University of the Arts disciplines. In the ensuing three decades, China's institutions of higher learning artistic disciplines everywhere, rapid development can be described in all disciplines, the number of students and professionals to set a fastest growing disciplines. According to related statistics, in China more than a thousand undergraduate colleges, currently more than 800 institutions established art majors, and mostly concentrated in the practical arts majors, constitute our diversified higher arts education development situation.

\section{Problems in the Education of the Art of Chinese Universities}

The moment, the number of China's various types of art culture of talent has been ranked first in the world, comprehensive training of personnel in colleges and universities which accounted for the majority proportion. But we also clearly can see that because of the development of artistic disciplines time is too short, too fast development, the scale of development is too large, too many students to develop, development targeting the vast majority of universities in the arts, arts curriculum construction, innovative student training, scientific research platform established artistic disciplines, arts core competence building and so there is a serious development disorder, did not form a complete set of the country, scientific, quantifiable specific artistic disciplines Teaching system. Art courses and teaching methods are generally used in liberal arts disciplines common evaluation mechanism and evaluation criteria, which is obviously not possible to effectively deal with specific issues art teaching personnel training. Art has its own special teaching professional rules, in particular is the art of learning has become a separate disciplines of higher education. If now to the concept of arts and sciences-oriented, full use of humanities and social science evaluation system to carry out the assessment, significantly affect normal development of art education because great harm. At present, many college art teachers fully reflect the views of this considerable, which for the future development of art education in Chinese universities will be a serious bottleneck.

Secondly, from the experience of Europe and the University of Art Education, the popularity of 'Humanities courses art history class in college, strengthen artistic quality of university students, the amount of hours of art courses and coverage should be raised to English, political, sports and other basic subjects equally important position. Art Courses currently serve mainly for the Chinese University School of Art student or Art Department, and for the vast majority of other college students, it can only be called one of the few art courses through the election, to learn the art knowledge fur, do not form a system of artistic life and artistic vision evaluation. This also shows that in the mind of many university teachers of art inside the service, not the whole school for all students, but also and professional schools, as only his artistic upbringing and education of students.

Again, arts curriculum standards of teaching Chinese universities there is a huge difference. In our country the tuition for students of art school students than the average much higher, and therefore many of the hastily implemented university art majors in addition to improve the number of subjects, another important consideration is to improve school funding. However, the result is often a consequence of the different colleges and universities in recruiting a large number of art students, the academic standards of their school teachers, school hardware conditions, the degree of standardization of teaching art courses there is a huge difference. For example, the creation of calligraphy professional university Take, for example, according to statistics in the number of Chinese universities which have 17, in which there are 28 teacher colleges, art schools in which there 
are 13, in college, there are four. But as far as I know the research, teaching staff of these schools there is a huge difference, university educated professional teachers calligraphy individual third-tier cities is actually even undergraduate college, school calligraphy syllabus set these courses also vary widely, graduates employment opportunities are also very narrow.

\section{The Urgent Problem to Be Solved in the Art Education of Our Country}

When Art becomes a separate category of Higher Education in China, We must first solve the problem is to learn the art of the academic discipline of Construction category. Well-known contemporary American cognitive psychologist and educator Jerome Bruner (Jerome Seymour Bruner 1915 ) in the 1960's proposed "Discipline structure" concept. He established the famous "structuralist" concept of education, said:. "Whether we choose what classes to ensure that students understand the basic structure of the body," he believes that the study of a knowledge category is to explore its structure system, not just for the field of study of the facts. To explore the structure of a subject is necessary to study these science practitioners. Research is a professional process of assimilation, absorption of experts in the field of knowledge, skills and traditional process, these experts define precisely what they covered subjects. Such studies can reveal the body structure, including its basic principles and key issues, a unique research tools and technical terminology. This direction of the university reform and development of China's artistic disciplines provides a good idea. Artistic disciplines development of our country must also get rid of the conventional teaching system disorder, not a unified curriculum, teaching methods and content teachers subjective, arbitrary large. To study in the United States as the representative of modern Western art discipline university education system, in the long-term development practice gradually formed a relatively stable, rational, scientific curriculum structure for its smooth development of art education in colleges and universities provide objective guarantees.

Second, is our artistic disciplines to the healthy development, we must establish a scientific, fair and sustainable artistic disciplines evaluation system. The establishment of a Chinese university to adapt to school environment and artistic talents training requirements of artistic disciplines evaluation system for the overall healthy development of Chinese art education has a profound impact. After decades of development, China Liberal Arts College has accumulated a large number of subjects evaluated experience, young art disciplines should be divided into two critical studies and absorb these outstanding experience. In line with the law on general education subjects in all education methods can absorb. But for higher arts education discipline itself particularity aspects such as the expression of artistic charm of artistic practice, artistic achievements also must be incorporated into the evaluation system of the subject to be. Universities try to avoid in the arts disciplines encountered when upgrading, job evaluation, research and reporting, achievement awards and other concerns Arts to develop practical interests, a simple blunt evaluation model applied arts and sciences, to recognize only text-based theory scientific research, and for the most characteristic expression of artistic disciplines and creative teaching practice class, award-winning achievements to be recognized or simply not recognized.

\section{Conclusion}

The art discipline is a very important academic category in the whole humanities system, and it also plays a decisive role in shaping the humanistic quality of college students. At the same time, the subject of art is not only a creative subject, but also a very practical subject. From the point of view of the development of educational history, only the establishment of creative on the basis of practice in the development of the discipline, it is the academic vitality and value, in order to meet the "practice theory practice" philosophy of law of a virtuous cycle of the dynamic. Through in-depth study of domestic and foreign art discipline discipline rule, reflect on our country in the development of education through the detour, and gradually solve the university art education, construct a really adapt 
to the environment of the higher education in our country university art discipline system, forming a theory combined with practice, professional disciplines and the integration of artistic disciplines benign development system. Further for the University of the arts disciplines (Professional) planning and development to provide effective perspective and decision-making, to promote the art of higher education benign, health, differences in the development of science and improve the overall quality of training talent in Art Institutes of higher learning in China.

President Hu Jintao at the National Conference on science and technology held in 20127 pointed out that the central government planning in 2020 to make China into the ranks of innovative countries. To achieve the emergence of innovative talents, the quality of the general public to improve the quality of the standard, "Innovative country" need large number have a style of thinking and innovative comprehensive quality of talents, to create the responsibility of cultivating talents with comprehensive thinking and innovative in China's higher education system has naturally become the primary goal of the University. Art subjects with original thinking characteristics as an important force in the development of the comprehensive quality of higher education, has its own inherent advantages. In the formation of guiding college students' divergent 205 thinking, creative ideas and unique expression, cultural and artistic accomplishments, encourage students' creativity, imagination, practice, avoid their fault on a single logical thinking, irreplaceable unique advantages of the subject. Compared with other types of colleges and universities, the university has incomparable advantages in the field of art education and nurturing innovative talents. Therefore, respect law of the development of the University of the arts, to avoid non art rules of art academic evaluation standard, build in line with the training mode of Chinese universities environment, to find the suitable for China's characteristics of running a school and teaching rules of art education system is an inevitable way for at this stage of the development of higher education.

\section{References}

[1]. Zhuang Yuan, "Comparison of Graduate Education and Reflection in Western art disciplines" Foreign Educational Research, pp.31-34, March 2004.

[2]. Xing Li, “Ordinary American University Art Education and Curriculum” Artistic exploration, pp.68-73, April 2005.

[3]. Liu Guizhen, "The Basic Idea of The Construction of Effective Art Education in A Comprehensive University” Journal of Northwest Normal University, pp.126-132, June 2012.

[4]. Xu Zifang "The comparison between Chinese and Western Art Education in Higher Education” Journal of Dalian University, pp.69-71, February 2008.

[5]. Liu Guizhen, Li Jingyu "The comparison between Chinese and Western Art Education in Higher Education” Contemporary Education and Culture, pp.92, July 2012.

[6]. Li Peiyu, "A Comparative Study on The Contents of Chinese and Foreign Art Majors" Art Circles, pp.28-53, February 2012.

[7]. DengTao, “Evaluation and Practice of Core Competence of University Art Discipline” Design Art Research, pp.93-97, May 2011.

[8]. Chu Zhaosheng, “Art 'own', what is the comprehensive university” China Education News, pp.255, June 2011.

[9]. Wang Wei, "Discipline based art education in the United States” Qilu Realm of Arts, pp.4-8, February 2009. 